\title{
Learning and Dietary Choice in Herbivores
}

\author{
Juan J. Villalba ${ }^{1}$ and Frederick D. Provenza ${ }^{2}$ \\ Authors are ${ }^{1}$ Research Assistant Professor, and ${ }^{2}$ Professor, Department of Wildland Resources, Utah State University, Logan, UT 84322-5230, USA
}

\begin{abstract}
Herbivores select diets from an array of plant species that vary in nutrients and plant secondary metabolites (PSM). The outcome is a diet higher in nutrients and lower in PSM than the average available in the environment. Food preferences in herbivores are controlled by dietary cues (i.e., flavor) associatively conditioned by the food's postingestive actions. The senses of smell, taste, and sight enable animals to discriminate among foods. Postingestive feedback calibrates sensory experiences-like or dislike-in accord with past and present experiences with a food's utility to the body. Thus, food selection can be viewed as the quest for substances in the external environment that provide a homeostatic benefit to the internal environment. Livestock form preferences for foods that supply needed nutrients and medicines and avoid foods that provide excesses of PSM and nutrients. In order to manifest this plasticity, animals need a variety of foods instead of being constrained to a single food or monoculture. Under natural conditions where diversity of plants is the rule, not the exception, eating a variety of foods is how animals meet their nutrient requirements and cope with-and likely benefit from-PSM in their diets. At certain doses, PSM may provide beneficial effects to herbivores and favor plant persistence and adaptability. If herbivores learn to utilize multiple plants, the costs of consuming PSM on animal production and well-being could be minimized and the benefits of PSM enhanced. Once individuals learn about the contextual benefits of consuming diverse foods, social models (e.g., mothers) could train new generations of herbivores by observational learning. We propose that by combining the concepts of animal learning and food diversity, it will be possible to create sustainable grazing systems with less dependence on fossil fuels and with enhanced benefits for soils, plants, herbivores, and people.
\end{abstract}

\section{Resumen}

Los herbívoros seleccionan dietas de diversas especies de plantas que varían en nutrientes y en metabolitos vegetales secundarios (PSM). El resultado es una dieta más alta en nutrientes y más baja en PSM que el promedio disponible en el ambiente. Las preferencias alimenticias en los herbívoros están controladas por señales dietéticas (e.g., sabor) asociativamente condicionadas por las acciones post-ingestiva de los alimentos. Los sentidos del olor, sabor y visión les permiten a los animales discriminar los alimentos. La reacción post-ingestiva calibra las experiencias sensoriales-gustar o no gustar-de acuerdo a las experiencias pasadas y presentes con una utilidad del alimento para el cuerpo. Por lo tanto, la selección de alimento puede interpretarse como la búsqueda de substancias en el ambiente externo que provean un beneficio homeostático para el ambiente interno. El ganado desarrolla preferencias por los alimentos que le proveen medicinas y nutrientes necesarios, y evitan aquellos que le brindan excesos de PSM y nutrientes. En orden para manifestar esta plasticidad, los herbívoros deben tener disponible una variedad de alimentos en vez de restringirse a un solo alimento o monocultivo. En condiciones naturales, donde la diversidad de plantas es la regla, y no la excepción, el consumo de una variedad de alimentos permite que los herbívoros alcancen sus requerimientos nutritivos, hacer frente al-y probablemente beneficiarse del-PSM en sus dietas. A ciertas dosis, el PSM pueden ser benéfico para los herbívoros, y favorecer la persistencia y adaptabilidad de la planta. Si los herbívoros aprenden a utilizar múltiples plantas, los costos de consumir PSM en la producción animal y el bienestar puede reducirse y se puede favorecer los beneficios de PSM. Una vez que los individuos aprenden sobre los beneficios contextuales de consumir diversos alimentos, modelos sociales (e.g., madres) podrían entrenar nuevas generaciones de herbívoros por observación. Nosotros proponemos que mediante la combinación de los conceptos de aprendizaje y diversidad de alimento, es posible crear sistemas de pastoreo sostenibles con una menor dependencia de combustibles fósiles y con un mayor beneficio para los suelos, plantas, herbívoros y seres humanos.

Key Words: aversions, choice, diet selection, flavor, postingestive feedback, preference

\section{INTRODUCTION}

Intensive livestock feeding systems commonly provide uniformly formulated foods, total-mixed rations, or monocultures.

This effort was supported by grants from the Utah Agricultural Experiment Station. This article is published with the approval of the Director, Utah Agricultural Experiment Station, and Utah State University, as journal paper number 7926.

Correspondence: Juan J. Villalba, Dept of Wildland Resources, Utah State University, Logan, UT 84322-5230, USA. Email: juan.villalba@usu.edu

Manuscript received 19 March 2008; manuscript accepted 7 June 2008
Underlying this approach is the assumption that domestic animals are unable to select diets to meet their nutritional needs. This assumption likely originated from early studies, where lactating dairy cows did not instinctively ingest recommended levels of calcium and phosphorus when offered dicalcium phosphate supplements ad libitum; indeed, many of the calcium-deficient animals never approached the novel source of calcium, and for those that did, intakes of calcium varied greatly, and the same was true with phosphorous (Coppock et al. 1972, 1976). Findings like these fostered the notion that domestication produced animals more responsive 
to food flavor than to nutritive value, and that acceptability rather than appetite for specific nutrients influences intake (Pamp et al. 1976). In other words, domestication erased nutritional wisdom and the innate ability to select needed nutrients, a trait that through evolution still confers survival value to wild herbivores (Coppock 1970).

However, ever since domestication of herbivores 8500 to 11000 years ago, livestock have been selecting nutritious diets on rangelands that contain an array of plant species that vary in nutritional value and chemical and mechanical defenses (Provenza 1991). Thus, animals met their nutrient requirements and avoided toxicosis long before the development of balanced rations and the emergence of the field of ruminant nutrition. The ability to select a balanced diet does not occur by chance alone. Livestock are active players in the field of nutrition; they are not just entities passively responding to natural selection or formulated rations.

\section{EFFECTS OF EXPERIENCE IN LIVESTOCK}

The assumption that livestock are unable to select diets to meet their needs has likely reduced the efforts aimed at understanding the animals' experiences with foods. For instance, in Latinsquare designs, nutritionists normally give an $8-15$-d adaptation interval between the period where a certain diet was fed and the next period where a new diet will be tested. This protocol assumes that once the rumen is adapted to the new diet, all the effects of the previous diet have been erased. Although the ruminal effects of an old diet may or may not be eliminated by the introduction of a new diet, experiences acquired from that old diet certainly cannot be eliminated from the central nervous system of the animal.

Past experiences have lifelong influences on behavior, but we seldom notice because we know or remember so little about the history of any animal. Experiences early in life influence gene expression (McCormick et al. 2000; Dufty et al. 2002; LeDoux 2002) and cause changes-neurological, morphological, physiological-in animals that influence their subsequent behavior (Provenza and Balph 1990; Provenza 1995a, 1996; Provenza and Villalba 2006).

Goats reared with their mothers on blackbrush-dominated land from 1 to $4 \mathrm{mo}$ of age consumed over 2.5 times more blackbrush than did goats naïve to blackbrush; experienced goats still consumed 30\% more blackbrush than inexperienced goats when allowed to choose between the poorly nutritious blackbrush (Coleogyne ramosissima) and alfalfa (Medicago sativa) pellets (Distel and Provenza 1991). Experience with low-quality forages enhances consumption and preference for other low-quality foods (Distel et al. 1994) and increases nitrogen retention (Distel et al. 1996).

Lambs exposed to wheat (Triticum aestivum) early in life with mother $\left(1 \mathrm{~h} \cdot \mathrm{d}^{-1}\right.$ for $5 \mathrm{~d}$ at 6 wk of age) consumed significantly more wheat $3 \mathrm{yr}$ later as adults than did animals that were exposed alone or that never consumed wheat (Green et al. 1984). Likewise, food intake and animal performance differed markedly during a 3-yr study of cows (5 yr of age) fed straw as a major part of their diet from December to May (Wiedmeier et al. 2002). Half of the cows ate straw for 2 mo as calves, whereas the other half had never seen straw. Through- out the 3-yr study, experienced cows ate more straw, lost less weight, maintained better body condition, produced more milk, and bred back sooner than cows not exposed to straw.

\section{ANIMAL LEARNING AND BEHAVIOR BY CONSEQUENCES}

Learning by definition is a relatively enduring change in behavior due to experience (Chance 1988), and in the previous section we provided evidence that experience strongly influences feeding behavior in livestock. To survive in an everchanging and unpredictable world requires that individuals experience the consequences of their behaviors and constantly modify those behaviors accordingly. Selection by consequences accounts for shaping and maintaining behavior of the individual and the evolution of cultures (Skinner 1981). Behavior by consequences is based on the premise that the consequences of behaviors affect the kinds and likelihoods of future behaviors. As environmental contingencies and consequences change, so does behavior, and it is the fundamental mechanism that allows organisms to adapt to the variability and unpredictability of the internal and external environment (Skinner 1984). No fixed goals, set points, or pre-established rules imbedded in the genetic code offer such plasticity. Rather, genes are in constant dialog with ever-changing environments and they are expressed as a function of interactions with social and biophysical environments (Provenza 2008).

The genetic code is the collective memory of the species that has been shaped by the environment through evolutionary time. During the lifetime of an individual, there are two other kinds of memories: 1) acquired by individual experience through the postingestive effects of food and 2) acquired through transgenerational knowledge (social learning; Provenza 1995b). These memories dynamically match the current-and changing-environment, allowing the individual to adapt to contemporary challenges that may differ from evolutionary or ecological experiences.

\section{POSTINGESTIVE FEEDBACK AND LEARNING}

A feedback system is a circular arrangement of functionally connected links. These links interact until the last link in the loop feeds back to the first link in the cycle, resulting in self-regulation of the system (Capra 1996). Functionally, a feedback system can be understood as a monitoring-action loop: When something changes in the body (e.g., a certain postingestive action) with the potential to alter the course of life, the body assesses or appraises such change (e.g., through receptors that inform the central nervous system) and acts accordingly (e.g., changes in food intake and preference; Damasio 2003). As a function of the actions performed by the animal a new signal will now interact with receptors, which will lead to a new action. Thus, by the recursive application of this loop the system rejuvenates itself and updates constantly, creating new decisions and fine-tuning new actions until homeostasis is achieved. The monitoringaction loop of a feedback system is particularly relevant in living organisms because homeostasis is not static but inherently dynamic: set points, equilibrium states, and biochemical 
processes change through time as organisms develop and preserve their integrity (Rose 1998). This dynamism implies that as conditions change in the short (e.g., within a meal) or long (e.g., months) term, responses will track such changes, always with the same final goal: homeostatic regulation.

\section{HOMEOSTATIC ENDEAVOR IN ANIMALS AND DIETARY CHOICE}

Food preference in herbivores develops due to the dynamic interplay between flavor and postingestive feedback, which are determined by an animal's physiological condition and a plant's chemical characteristics (Provenza 1996; Provenza and Villalba 2006). Taste (as well as smell and sight) allows animals to discriminate among foods. Thus, flavors and other cues are labels animals use to distinguish specific foods. Postingestive feedback calibrates a food's flavor with its homeostatic utility. If a particular food provides chemicals that are required by an animal at a certain point in space and time, then the animal will associate the taste of that food with a benefit to the body and preference will increase. In contrast, if a food supplies chemicals that provide negative effects to the body or compounds that are not needed in that particular point in time (e.g., excess nutrients), postingestive feedback will cause a decline in food preference and intake. On this basis, herbivores preferentially ingest foods high in nutrients and low in toxins, but they avoid specific nutrients when needs are met (Villalba and Provenza 1999) and they eat toxins when toxins complement each other and toxincontaining foods provide a benefit to the animal (Villalba et al. 2004). Thus, our thesis is that food selection in animals can be interpreted as the constant quest for substances in the external environment that provide a homeostatic benefit to the internal environment. Nutrients, toxins, and medicines are labels scientists use to better comprehend foraging complexity; for the animal in a dynamic homeostatic quest, ingesting nutrients, toxins, and medicines are means to the same end-staying well (Villalba and Provenza 2007).

\section{Evidence of Learning Based on the Postingestive Effects of Nutrients}

Ruminants learn to discriminate between foods based on postingestive feedback from nutrients. Sheep and goats fed diets low in energy and protein prefer flavored low-quality foods previously paired with intraruminal infusions of energy (starch, propionate, acetate) or nitrogen (urea, casein, gluten), respectively (Villalba and Provenza 1996, 1997a, 1997b, 1997c; Arsenos et al. 2000; Duncan and Young 2002). Sheep balance the ingestion of an energy-rich meal by increasing preference for foods high in protein and vice versa. For example, given preloads of energy or nitrogen, lambs prefer flavors previously paired with nitrogen or energy, respectively, during the ensuing meals (Villalba and Provenza 1999). Likewise, dairy cows fed high levels of protein in the barn subsequently avoid eating plants with higher nitrogen concentrations when given choices while they are foraging on pasture (Emmik 2007). Sheep respond to synchrony in the rates of nutrient fermentation. Palatability increases with the synchronous supply of energy and protein to the host and decreases when there is an excess of either (Kyriazakis and Oldham 1993; Villalba and Provenza 1997b; Early and Provenza 1998). Finally, minerals also influence preferences. Lambs with low concentrations of serum inorganic phosphorous and calcium increase preferences for flavors and supplements that provide those minerals (Villalba et al. 2006a, 2008).

\section{Evidence of Learning Based on the Postingestive Effects of Plant Secondary Metabolites}

All plants, including garden vegetables, contain plant secondary metabolites (PSM; Osweiler et al. 1985; Palo and Robbins 1991; Cheeke 1998), but herbivores seldom consume enough PSM to result in poisoning because they regulate their intake of foods that contain PSM (Provenza 1995b, 1996; Foley et al. 1999). For instance, oral gavage of toxins causes dose-dependent decreases in intake of foods that contain the toxins (Wang and Provenza 1997). Goats learn to avoid the current season's twigs of the shrub blackbrush, which are high in condensed tannins, by associating the flavor of blackbrush with aversive postingestive consequences. These animals also avoid otherwise palatable novel foods when they are mixed with purified condensed tannins or the toxicant lithium chloride (Provenza et al. 1990).

\section{Social Learning}

Socializing enhances learning efficiency because each animal no longer has to discover everything through trial and error where, in the case of foraging, the animal learns after experiencing the postingestive effects of food. In observational learning, experience of the learner consists of exposure to a model (e.g., mother) that is performing a certain behavior (Chance 1988). Naïve animals familiar with only a limited number of foods in a landscape may be less likely to learn about the potential benefits of ingesting novel plants or about the postingestive complementarities and interactions among novel-novel and novel-familiar plants. Pioneering animals in a social group-those that learn mainly based on consequencesonce positioned in the right place in time and space, may learn about novel foods and the beneficial effects of specific foods or combinations of foods. Once an individual learns, the new behavior may then spread through the group, becoming part of the foraging behavior of females (Huffman 2001), who can then transmit those behaviors to their offspring. Such transmission of information across generations occurs in livestock. For instance, when offered a choice, lambs avoid or prefer foods as a function of their mothers' avoidances or preferences (Mirza and Provenza 1990, 1992). When a mother's food selection behavior (eat or avoid) is subsequently reinforced by postingestive feedback from nutrients or toxins (positive or negative), her offspring respond strongly (eat or avoid) to a food (Provenza et al. 1993). Such knowledge then becomes a part of the culture, wherein young animals learn from their ancestors through their mothers.

\section{Learning and Food Intake}

As with food choice, food intake can be interpreted as a learning process. After selecting a certain food (e.g., in diverse pastures), or approaching the only food available for consumption (e.g., in monocultures), the animal has control over the amount of food that will enter its digestive system. As with food preference, this process is regulated by the experiences the individual had with the 
food's postingestive actions. For instance, sheep are extremely reluctant to eat poor-quality roughages like straw but they significantly increase straw intake when a more nutritious food (grass hay) is put into the rumen while animals eat straw (Greenhalgh and Reid 1971). Likewise, lambs receiving intraruminal infusions of a nutrient (starch) while they ate straw showed higher straw intake, intake rate, and bite size than lambs that received intraruminal infusions of vehicle (water). Thus, high intakes of straw can be interpreted as an enhanced incentive or drive to eat straw because of its association with a readily available source of energy (Villalba and Provenza 2000). Preruminant and ruminant lambs reduce their intake when offered diets deficient in limiting amino acids and they readily sample other foods that may help them correct the deficiency (Rogers and Egan 1975; Egan and Rogers 1978). Collectively, these results suggest that low intake of poor-quality foods or foods with nutrient imbalances are in part a reflection of the dislike animals manifest for such foods after experiencing their postingestive actions.

\section{Monotony, Nutrients, and Plant Secondary Metabolites}

Plant secondary metabolites constrain intake. Thus, PSM satiate herbivores, and the more quickly plants satiate foragers, the more likely these plants are to survive (Garcia 1989). However, from the animal perspective, a reduced intake implies constraints in productivity. Moreover, it is well known that at certain doses PSM negatively impact animal cells, tissues, and metabolic processes (Cheeke and Shull 1985; Cheeke 1988; Osweiler et al. 1985). Thus, one of the objectives for improving the quality of pastures has been the reduction in concentration of PSM in forages. Through breeding programs with crops and pastures the biochemical balance in plants has been altered to significantly favor primary (mainly energy) over secondary compounds (Provenza et al. 2007). This approach makes sense with regard to pastures when plants grow in monocultures. In other words, when livestock are forced to consume singlespecies diets, a reduction in the concentration of PSM is appropriate because secondary compounds limit intake of a single food. However, ancestors of livestock did not eat single foods; rather, they selected their diets from a diverse array of plants, as do wild herbivores and livestock foraging on rangelands today (Provenza et al. 2003, 2007). Diverse diets may allow animals to maintain high levels of intake while consuming plants that contain PSM. Plant secondary compounds at certain doses may provide beneficial effects to herbivores, such as combating pathogens (see below), providing antioxidant and immunity-enhancing activities (von Schönfeld et al. 1997; Mishima et al. 2004), and reducing nitrogen loses (Reed 1995) and CH4 emissions (Min et al. 2005).

There may be important advantages for plants and herbivores if PSM are present in grazing systems. All plants produce PSM vital for attracting pollinators and seed dispersers, helping plants recover from injury, protecting plants from ultraviolet radiation, and defending plants against pathogens and herbivores (Rosenthal and Janzen 1979; Rosenthal and Berenbaum 1992). Moreover, the lack of PSM may negatively impact plant persistence and adaptability. For instance, tall fescue infected with the Neotyphodium endophyte produces ergot alkaloids responsible for fescue toxicosis in grazing animals. Nevertheless, the presence of the endophyte has been associated with many of the positive attributes of tall fescue, including its wide adaptation and tolerance of biotic and abiotic stress (Asay et al. 2001).

\section{HOW DO HERBIVORES MINIMIZE THE NEGATIVE EFFECTS OF PLANT SECONDARY COMPOUNDS?}

If PSM at certain doses provide benefits to herbivores and plants, how can we keep PSM in grazing systems without negatively impacting animals? There is a fundamental dichotomy with ingesting PSM. At low concentrations they may have positive impacts on animal health and well-being, whereas at higher doses the impacts become negative. It is likely that this dichotomy operates along a gradient. Likewise, nutrients are required for survival and reproduction, but at excessive amounts they have negative impacts on animal tissues and metabolic processes (Provenza 1996; Provenza and Villalba 2006). There are at least two mechanisms by which the negative effects of PSM can be minimized in herbivores: plant diversity and the ingestion of medicines.

\section{Plant Diversity}

We presented evidence in previous sections supporting the notion that grazing animals learn to discriminate among foods based on the postingestive effects of nutrients and PSM. Thus, having available the appropriate alternatives and eating a variety of foods is how animals cope with, and likely benefit from, secondary compounds in their diets.

A plant community with a diverse array of PSM may allow animals to harvest higher amounts of nutrients while maintaining PSM intake below toxic levels. This is because PSM that affect different organs and detoxification pathways are likely to be less toxic when ingested as a dilute mixture than when each PSM is ingested in a larger dose (Freeland and Janzen 1974). Brushtail possums (Trichosurus vulpecula) maintain a higher intake of food when allowed to select from two diets containing phenolics and terpenes than when given access to the diets individually (Dearing and Cork 1999). Mule deer (Odocoileus hemionus) also eat more when offered both sagebrush (Artemisia tridentata) and juniper (Juniperus communis), plants that contain different terpenes, than when consuming only sagebrush or juniper (Smith 1959). Sheep eat more when offered choices of foods with various toxins that affect different detoxification mechanisms (Burritt and Provenza 2000; Villalba et al. 2004; Lyman et al. 2008). In contrast, when toxins impact the same detoxification pathway or are antagonistic, ingestion of toxins decreases (Burritt and Provenza 2000).

A diverse intake of PSM may also lead to toxin neutralization or inactivation, which in turn could reduce susceptibility to PSM. Rats (Rattus norvegicus) eat more of a combination of foods containing tannins and saponins because tannins and saponins chelate in the intestinal tract, reducing the negative effects of both components (Freeland et al. 1985). Thus, interactions among PSM-containing foods can lead to complementary relationships such that eating a combination of foods may exceed the benefit of consuming any one food in isolation (Tilman 1982).

Experiences with combinations of PSM-containing foods that are complementary may promote higher preference for 
these foods. As an example, lambs that learn to eat foods containing terpenes, tannins, and oxalates eat more when they can select two of the foods offered simultaneously than when they are offered only one food. Subsequently, lambs offered foods containing all three PSM eat more than lambs offered any two of the PSM, and their intake is comparable to lambs offered the foods without PSM (Controls), suggesting foods with tannins, terpenes, and oxalates are complementary (Villalba et al. 2004). Experience with those complementary PSM and the availability of nutritious alternatives both influenced food choice when feeding behavior of lambs with three months' experience mixing foods were compared with lambs naive to those foods (Villalba et al. 2004). Experienced and naïve lambs were offered five foods, two of them nutritious, safe, and familiar to all of the lambs (alfalfa and a 50:50 mix of ground alfalfa:ground barley [Hordeum vulgare]) and three of them containing PSMs, familiar to only experienced lambs (a ground ration with either tannins, terpenes, or oxalates). Half of the lambs were offered the nutritious foods ad libitum, and the remaining lambs were offered only $200 \mathrm{~g}$ of each nutritious food daily. Throughout the study, lambs ate less of the foods with PSM if they had ad libitum as opposed to restricted access to the nutritious, safe alternatives. However, experienced lambs ate significantly more of the foods containing the PSM, whether access to the safe alfalfa-barley alternatives was ad libitum (i.e., when they were allowed to avoid PSM-containing foods completely) or restricted. These differences in food preferences and intake persisted during trials a year later. In a follow-up study, when access to nutritious foods was restricted to $10 \%, 30 \%, 50 \%$, or $70 \%$ of ad libitum, animals ate more of the foods with PSM and they gained more weight with the increased restriction in nutritious foods (Shaw et al. 2006). This illustrates animals must be encouraged to learn to eat unfamiliar foods that contain complementary PSM.

In another study, sheep learned to eat a low-quality food with tannins $(\mathrm{T})$ and a high-quality food $(\mathrm{H})$ in two different temporal arrangements (Villalba et al. 2006b). In one case, sheep were fed $\mathrm{H}$ for $12 \mathrm{~d}$ followed by $\mathrm{T}$ for $12 \mathrm{~d}$ such that their potentially synergistic effects were dissociated into 2 distinct feeding periods. In the other case sheep were fed $\mathrm{H}$ and $\mathrm{T}$ simultaneously for $12 \mathrm{~d}$ such that their effects were associated within the same meal. Subsequently, all sheep could forage at locations containing $\mathrm{H}$ and $\mathrm{T}$, only $\mathrm{H}$, or only $\mathrm{T}$. Sheep that initially ate both foods in a meal always ate more $\mathrm{T}$ than those that initially experienced the foods in two distinct feeding periods, even when $\mathrm{H}$ was available ad libitum. As $\mathrm{H}$ decreased in abundance, lambs that learned to mix both foods in a meal foraged more opportunistically and remained longer at locations with both $\mathrm{H}$ and $\mathrm{T}$ or with just $\mathrm{T}$ (Villalba et al. 2006b).

Collectively, our analysis suggests initial conditions-past experiences and contingencies-that encourage animals to learn to mix diets that contain PSM and nutrients increases use of less-palatable foods and allows herbivores to cope with PSM. As mentioned above, PSM at certain doses may provide beneficial effects to herbivores.

\section{Medicines}

The previous analysis suggests herbivores can potentially counteract the negative effects of PSM in their bodies through foraging behavior. Although enzymatic detoxification has received the most attention as a mechanism used by mammals to cope with PSM (Cheeke and Schull 1985; Cheeke 1998), ingestion of medicines in order to prevent or neutralize toxicosis suggests an additional important means of detoxification in animals (Diamond 1999). As an example, Peruvian parrots (Amazona aestiva) preferred soils with much higher cation-exchange capacity than adjacent bands of rejected soils. Selected soils contained kaolin and mica, which bind PSM such as alkaloids and tannic acid. Thus, detoxification and cytoprotection are likely functions of geophagy for parrots and herbivores with similar ecologies (Gilardi et al. 1999).

We have hypothesized that food selection in animals can be interpreted as the constant quest for substances in the external environment that provide a homeostatic benefit to the internal environment. From this hypothesis we predict that animals learn to seek substances such as medicines when experiencing malaise. Consistent with this, sheep increase intake of medicines such as polyethylene glycol (PEG), a polymer that attenuates the aversive effects of tannins, as tannin concentrations in their diet increase (Provenza et al. 2000). They discriminate the medicinal effects of PEG from nonmedicinal substances by selectively increasing intake of PEG after eating a meal high in tannins (Villalba and Provenza 2001). They also forage in locations where PEG is present, rather than where it is absent, when offered nutritious foods high in tannins in different locations (Villalba and Provenza 2002). Multiple malaise-medicine associations in herbivores are also possible. Sheep had to learn about the benefits of specific medicines at alleviating the effects of illness-inducing foods in order to choose the right treatment. They selected an antiacid (sodium bentonite) after ingesting a meal that causes ruminal acidosis, and they preferred substances that neutralize the effects of tannins (PEG) and oxalic acid (dicalcium phosphate) after ingesting meals with these PSM (Villalba et al. 2006c). Control animals that were not given the opportunity to learn about the association of medicine-malaise (e.g., they consumed the medicine without experiencing malaise) did not choose the right medicine, and the pattern of medicine selection did not change after consuming different illness-inducing foods (Villalba et al. 2006c).

\section{Plant Secondary Compounds as Medicines}

Plant secondary metabolites cause postingestive consequences in herbivores, typically through their negative actions on several cellular and metabolic processes (Cheeke and Schull 1985; Cheeke 1998). Thus, it is possible these compounds can also have their negative actions across several trophic levels (Lozano 1998). For instance, PSM exert their negative actions on living organisms such as bacteria, parasites, and fungi that inhabit herbivores' bodies and cause decreases in health (Engel 2002). Plant-derived alkaloids, terpenes, and phenolics have antiparasitic properties (Hocquemiller et al. 1991; Kayser et al. 2003) and sesquiterpene lactones have antitumorigenic, antiamoebic, antibacterial, antifungal, and cardiotonic properties (Picman 1986; Robles et al. 1995; Huffman et al. 1998).

The increasing prevalence of anthelmintic resistance has provided a spur for research into alternative/novel approaches to the control of internal parasites in livestock (Jackson and Miller 2006). Condensed tannins have significant antiparasitic 
properties in herbivores directly, through specific anthelmintic effects (Athanasiadou et al. 2000), or indirectly, by increasing the resistance and resilience of animals to parasitic infections as a consequence of improved protein nutrition (Min and Hart 2003). Herbivores feeding on plants with tannins show lower nematode burdens, lower fecal egg counts, and higher body gains than those feeding on plants of similar nutritional qualities but without tannins (Niezen et al. 2002; Min et al. 2004).

Given the abilities of animals to self-medicate, and the antiparasitic effects of condensed tannins, herbivores may learn to diminish the influence of internal parasites by eating foods high in tannins (Hutchings et al. 2003; Athanasiadou and Kyriazakis 2004). Parasitized sheep may sense the negative effects of parasitic burdens: they avoid feces-contaminated pastures (Hutchings et al. 2002), and graze further from the soil surface than nonparasitized animals in order to minimize infection (Hutchings et al. 2003). Likewise, parasitized sheep may experience relief following ingestion of an antiparasitic agent as they decrease rejection of feces-contaminated pastures after treatment with an anthelmintic drench (Hutchings et al. 2002). Recent experiments show parasitized sheep are willing to consume tannins-which decrease fecal egg counts in their feces-even if tannins are mixed in foods that do not provide any nutritional benefits (L. D. Lisonbee, J. J. Villalba, F. D. Provenza, and J. O. Hall, unpublished results, 2008) and parasitized lambs select higher amounts of foods with tannins than nonparasitized animals (J. J. Villalba, F. D. Provenza, J. O. Hall, and L. D. Lisonbee, unpublished results, 2008).

\section{IMPLICATIONS}

Grazing animals learn about the postingestive effects of specific foods. They learn to prefer foods that provide needed nutrients and medicinal effects, they learn to avoid PSM, and they are able to mix foods in diverse systems such that the effects of PSM are attenuated. Managers could use these principles to allow livestock to build their own diets within the overall objective of enhancing in a sustainable way the production and health of animals, plants, and soils.

Monocultures in some situations may be excessive or deficient in certain nutrients and thus provide an unbalanced diet to animals. Plant secondary compounds in monocultures constrain intake, although PSM at certain concentrations may supply benefits to the plant and to the herbivore. Thus, an alternative to single-species diets is to offer animals a variety of foods that differ in primary and secondary metabolites, thereby enabling them to obtain the nutrition and health benefits.

If animals learn to utilize multiple plants in diverse systems, the costs of consuming PSM on animal production, health, and well-being could be minimized and the benefits of PSM enhanced. For instance, it may not be necessary to force parasitized animals to consume plants high in PSM in monocultures (e.g., deworming paddocks) in order to reduce parasitic burdens, with the concomitant costs that this provides in terms of production and well-being (Athanasiadou and Kyriazakis 2004). Animals grazing on several plant species may be able to self-medicate and at the same time achieve a higher nutrient intake. Recent research suggests cattle can eat more and have higher feed efficiencies when they graze mixtures of fescue (Festuca arundinacea), brome (Bromus inermis), alfalfa, and birdsfoot trefoil (Lotus corniculatus) than when fed in monocultures (R. D. Wiedmeier, unpublished results, 2007).

Animals that learn about the benefits of diverse pastures will likely consume PSM-containing vegetation when needed. Thus, individual animals will not receive an average dose, similar to situations when they are drenched with a specific chemical, but a dose that is a function of need. It could be possible to add to the high-quality forages herbivores normally consume strips of PSM-containing forages that provide a specific benefit (i.e., combat parasites). These forages could be understood as medicine kits, where animals will graze when needed, and their nutritional state will not be compromised because they will continue to have access to other nutritious foods.

When incorporating animal learning into diverse grazing systems we will need to address issues regarding how animals should be trained so they learn to ingest an optimal and complementary combination of nutrients from diverse foods. We will also need to understand how animals should be managed in biochemically diverse pastures so they recognize ingesting doses of PSM that provide medicinal benefits without depressing their welfare and productivity. Animals that learn based on consequences should be positioned in the right place, at the right time so they learn about the postingestive effects of specific plant species or about the contextual postingestive effects of combinations of plant species consumed in the same meal. As mentioned above, once certain individuals learn, social models (e.g., mothers) could be used to train new generations of herbivores by observational learning.

An understanding of the trade-offs of nutrition and PSM will help develop pasture mixes in proportions that match the preferences manifested by grazing animals. Time allocated to foraging on specific plants when given a choice among strips of species with different concentrations of nutrients and PSM may reflect an animal's specific nutritional and medicinal needs. For instance, parasitized and nonparasitized animals offered choices among strips of different forages may spend different amounts of time grazing in forages with higher concentrations of PSM. As recent research suggests (J. J. Villalba, F. D. Provenza, J. O. Hall, and L. D. Lisonbee, unpublished results, 2008) parasitized lambs incorporate higher levels of tannin-containing foods in their diets than nonparasitized lambs.

Under natural conditions where diversity of plants is the rule, not the exception, eating a variety of foods is how animals cope with, and likely benefit from, secondary compounds in their diets. In gaining an understanding of the role of natural diversity in agricultural systems, we do not simply need to mimic nature, but to appreciate and utilize key concepts as the basis for improved management systems (Provenza et al. 2007).

\section{LITERATURE CITED}

Arsenos, G., I. Kyriazakis, and B. J. Tolkamp. 2000. Conditioned feeding responses of sheep towards flavoured foods associated with the administration of ruminally degradable and/or undegradable protein sources. Animal Science 71:597-606.

Asay, K. H., K. B. Jensen, and B. L. Waldron. 2001. Responses of tall fescue cultivars to an irrigation gradient. Crop Science 41:350-357. 
Athanasiadou, S., And I. Kyriazakis. 2004. Plant secondary metabolites: antiparasitic effects and their role in ruminant production systems. Proceedings of the Nutrition Society 63:631-639.

Athanasiadou, S., I. Kyriazakis, F. Jackson, and R. L. Coop. 2000. Effects of shortterm exposure to condensed tannins on adult Trichostrongylus colubriformis. Veterinary Record 146:728-732.

Burritt, E. A., and F. D. Provenza. 2000. Role of toxins in intake of varied diets by sheep. Journal of Chemical Ecology 26:1991-2005.

Capra, F. 1996. The web of life. New York, NY, USA: Anchor Books, Doubleday. $347 \mathrm{p}$.

Chance, P. 1988. Learning and behavior. Belmont, CA, USA: Wadsworth. 330 p.

Cheeke, P. R. 1998. Natural toxicants in feeds, forages, and poisonous plants. Danville, IL, USA: Interstate. 465 p.

Cheeke, P., And L. R. Shull. 1985. Natural toxicants in feeds and poisonous plants. Westport, CT, USA: Avi Publishing. 492 p.

Coppock, C. E. 1970. Free choice mineral consumption by dairy cattle. In: Proceedings of the Cornell Nutrition Conference. Ithaca, NY, USA: New York State College of Agriculture. p. 29-35.

Coppock, C. E., R. W. Everett, and R. L. Belyea. 1976. Effect of low calcium or low phosphorus diets on free choice consumption of dicalcium phosphate by lactating dairy cows. Journal of Dairy Science 59:571-580.

Coppock, C. E., R. W. Everett, and W. G. Merrill. 1972. Effect of ration on free choice consumption of calcium-phosphorus supplements by dairy cattle. Journal of Dairy Science 55:245-256.

DamasIO, A. 2003. Looking for Spinoza: joy, sorrow, and the feeling brain. New York, NY, USA: Harcourt. $356 \mathrm{p}$.

Dearing, M. D., and S. Cork. 1999. Role of detoxification of plant secondary compounds on diet breadth in a mammalian herbivore, Trichosurus vulpecula. Journal of Chemical Ecology 25:1205-1219.

DIAmOND, J. 1999. Dirty eating for healthy living. Nature 400:120-121.

Distel, R. A., and F. D. Provenza. 1991. Experience early in life affects voluntary intake of blackbrush by goats. Journal of Chemical Ecology 17:431-450.

Distel, R. A., J. J. VILLaLba, AND H. E. LaboRde. 1994. Effects of early experience on voluntary intake of low-quality roughage by sheep. Journal of Animal Science 72:1191-1195.

Distel, R. A., J. J. Villalba, H. E. Laborde, and M. A. Burgos. 1996. Persistence of the effects of early experience on consumption of low-quality roughage by sheep. Journal of Animal Science 74:965-968.

Dufty, A. M., JR., J. Clobert, and A. P. Moller. 2002. Hormones, developmental plasticity and adaptation. Trends in Ecology and Evolution 17:190-196.

Duncan, A. J., And S. A. Young. 2002. Can goats learn about foods through conditioned food aversions and preferences when multiple food options are simultaneously available? Journal of Animal Science 80:2091-2098.

Early, D., and F. D. Provenza. 1998. Food flavor and nutritional characteristics alter dynamics of food preference in lambs. Journal of Animal Science 76:728-734.

Egan, A. R., and Q. R. Rogers. 1978. Amino acid imbalance in ruminant lambs. Australian Journal of Agricultural Research 29:1263-1279.

Емміск, D. L. 2007. Foraging behavior of dairy cattle on pastures [thesis]. Logan, UT, USA: Utah State University. 243 p.

Engel, C. 2002. Wild health. Boston, MA, USA: Houghton Mifflin. 276 p.

Foley, W. J., G. R. Iason, and C. McArthuR. 1999. Role of plant secondary metabolites in the nutritional ecology of mammalian herbivores: how far have we come in 25 years? In: H. G. Jung and G. C. Fahey, Jr. [EDS.]. Proceedings of the 5th International Symposium on Nutrition of Herbivores. Nutritional Ecology of Herbivores. Champaign, IL, USA: American Society of Animal Science. p. 130-209.

Freeland, W. J., P. H. Calcott, and L. R. Anderson. 1985. Tannins and saponin: interaction in herbivore diets. Biochemical Systematics and Ecology 13:189-193.

Freeland, W. J., And D. H. Janzen. 1974. Strategies in herbivory by mammals: the role of plant secondary compounds. American Naturalist 108:269286.

GARCIA, J. 1989. Food for Tolman: cognition and cathexis in concert. In: T. Archer and L. Nilsson [EDS.]. Aversion, avoidance and anxiety. Hillsdale, NJ, USA: Lawrence Earlbaum. p. 45-85.
Gilardi, J. D., S. S. Duffey, C. A. Munn, and L. A. Tell. 1999. Biochemical functions of geophagia in parrots: detoxification of dietary toxins and cytoprotective effects. Journal of Chemical Ecology 25:897-922.

Green, G. C., R. L. Elwin, B. E. Mottershead, and J. J. Lynch. 1984. Long-term effects of early experience to supplementary feeding in sheep. Proceedings of the Australian Society of Animal Production 15:373-375.

Greenhalgh, J. F. D., And G. W. ReID. 1971. Relative palatability to sheep of straw, hay and dried grass. British Journal of Nutrition 26:107-116.

Hocquemiller, R., D. Cortes, G. J. Arango, S. H. Myint, A. Cave, A. Angelo, V. Munoz, AND A. FouRnet. 1991. Isolation and synthesis of espintanol, a new antiparasitic monoterpenes. Journal of Natural Products 54:445-452.

Huffman, M. A. 2001. Self-medicative behavior in the African great apes: an evolutionary perspective into the origins of human traditional medicine. BioScience 51:651-661.

Huffman, M. A., H. Ohigashi, M. Kawanaka, J. E. Page, G. C. Kirby, M. Gasquet, A. Murakami, and K. Koshimizu. 1998. African great ape self-medication: a new paradigm for treating parasite disease with natural medicines? In: $\mathrm{H}$. Ageta, N. Aimi, Y. Ebizuka, T. Fujita, and G. Honda [EDS.]. Towards natural medicine research in the 21st century. Amsterdam, Netherlands: Elsevier Science B.V. p. 113-123.

Hutchings, M. R., S. Athanasiadou, I. Kyriazakis, and I. Gordon. 2003. Can animals use foraging behaviour to combat parasites? Proceedings of the Nutrition Society 62:361-370.

Hutchings, M. R., I. J. Gordon, I. Kyriazakis, E. Robertson, and F. Jackson. 2002. Grazing in heterogeneous environments: infra- and supra-parasite distributions determine herbivore grazing decisions. Oecologia 132:453-460.

Jackson, F., And J. Miller. 2006. Alternative approaches to control-quo vadit? Veterinary Parasitology 139:371-384.

Kayser, O., A. F. Kiderlen, and S. L. Croft. 2003. Natural products as antiparasitic drugs. Parasitology Research 90:S55-S62.

KyriazAKIS, I., AND J. D. OLDham. 1993. Diet selection in sheep: the ability of growing lambs to select a diet that meets their crude protein (nitrogen $\times 6.25$ ) requirements. British Journal of Nutrition 69:617-629.

LeDoux, J. 2002. Synaptic self: how our brains become who we are. New York, NY, USA: Viking Penguin. 406 p.

LozAno, G. A. 1998. Parasitic stress and self-medication in wild animals. In: A. P. Moler, M. Milinski, and P. J. B. Slater [EDS.]. Advances in the study of behavior. London, United Kingdom: Elsevier Science. p. 291-317.

Lyman, T., F. D. Provenza, and J. J. Villalba. 2008. Sheep foraging behavior in response to interactions among alkaloids, tannins and saponins: implications for chemical and taxonomic diversity in pasture ecosystems. Journal of the Science of Food and Agriculture 88:824-831.

McCormick, J. A., V. Lyons, M. D. Jacobson, J. Noble, J. Diorio, M. Nyirenda, S. Weaver, W. Ester, J. L. Yau, M. J. Meaney, J. R. Seckl, and K. E. Chapman. 2000. 5'-heterogeneity of glucocorticoid receptor messenger RNA is tissue specific: differential regulation of variant transcripts by early-life events. Molecular Endocrinology 14:506-517.

Min, B. R., ANd S. P. HaRT. 2003. Tannins for suppression of internal parasites. Journal of Animal Science 81:E102-E109.

Min, B. R., W. E. Pinchoak, J. D. Fulford, and R. Puchala. 2005. Wheat pasture bloat dynamics, in vitro ruminal gas production, and potential bloat mitigation with condensed tannins. Journal of Animal Science 83:1233-1331.

Min, B. R., W. E. Pomroy, S. P. Hart, and T. Sahlu. 2004. The effect of short-term consumption of a forage containing condensed tannins on gastro-intestinal nematode parasite infections in grazing wether goats. Small Ruminant Research 51:279-283.

Mirza, S. N., And F. D. Provenza. 1990. Preference of the mother affects selection and avoidance of foods by lambs differing in age. Applied Animal Behaviour Science 28:255-263.

Mirza, S. N., and F. D. Provenza. 1992. Effects of age and conditions of exposure on maternally mediated food selection by lambs. Applied Animal Behaviour Science 33:35-42.

Mishima, S., K. Saito, H. Maruyama, M. Inoue, T. Yamashita, T. Ishida, and Y. Gu. 2004. Antioxidant and immuno-enhancing effects of Echinacea purpurea. Biological Pharmacology Bulletin 27:1004-1009. 
Niezen, J. H., W. A. G. Charleston, H. A. Robertson, D. Shelton, G. C. Waghorn, and R. GreEn. 2002. The effect of feeding sulla (Hedysarum coronarium) or lucerne (Medicago sativa) on lamb parasite burdens and development of immunity to gastrointestinal nematodes. Veterinary Parasitology 105:229-245.

Osweller, G. D., T. L. Carson, W. B. Buck, and G. A. Van Gelder. 1985. Clinical and diagnostic veterinary toxicology. Dubuque, IA, USA: Kendall/Hunt. $494 \mathrm{p}$.

Palo, R. T., And C. T. Robbins. 1991. Plant defenses against mammalian herbivory. Boca Raton, FL, USA: CRC Press. 192 p.

Pamp, D. E., R. D. Goodrich, and J. C. Meiske. 1976. A review of the practice of feeding minerals free choice. World Review of Animal Production 12:13-18.

Picman, A. K. 1986. Biological activities of sesquiterpene lactones. Biochemical Systematics and Ecology 14:255-281.

Provenza, F. D. 1991. Behavior and nutrition are complementary endeavors. In: Proceedings 2nd Grazing Livestock Nutrition Conference. Stillwater, OK, USA: Oklahoma State University, Agricultural Experiment Station MP-133. p. 157-169.

Provenza, F. D. 1995a. Postingestive feedback as an elementary determinant of food preference and intake in ruminants. Journal of Range Management 48:2-17.

ProvenzA, F. D. 1995b. Tracking variable environments: there is more than one kind of memory. Journal of Chemical Ecology 21:911-923.

Provenza, F. D. 1996. Acquired aversions as the basis for varied diets of ruminants foraging on rangelands. Journal of Animal Science 74:2010-2020.

Provenza, F. D. 2008. What does it mean to be locally adapted and who cares anyway? Journal of Animal Science 86:E271-E284.

Provenza, F. D., and D. F. Balph. 1990. Applicability of five diet-selection models to various foraging challenges ruminants encounters. In: R. N. Hughes [ED.] Behavioural mechanisms of food selection. NATO ASI Series G: Ecological Sciences Volume 20. Berlin, Germany: Springer-Verlag. p. 423-459.

Provenza, F. D., E. A. Burritt, T. P. Clausen, J. P. Bryant, P. B. Reichardt, and R. A. Distel. 1990. Conditioned flavor aversion: a mechanism for goats to avoid condensed tannins in blackbrush. American Naturalist 136:810-828.

Provenza, F. D., E. A. Burritt, A. Perevolotsky, and N. Silanikove. 2000. Selfregulation of intake of polyethylene glycol by sheep fed diets varying in tannin concentrations. Journal of Animal Science 78:1206-1212.

Provenza, F. D., J. J. LYnch, and J. V. Nolan. 1993. The relative importance of mother and toxicosis in the selection of foods by lambs. Journal of Chemical Ecology 19:313-323.

Provenza, F. D., and J. J. Villalba. 2006. Foraging in domestic vertebrates: linking the internal and external milieu. In: V. L. Bels [ED.]. Feeding in domestic vertebrates: from structure to function. Oxfordshire, United Kingdom: CABI. p. 210-240.

Provenza, F. D., J. J. Villalba, L. E. Dziba, S. B. Atwood, and R. E. Banner. 2003. Linking herbivore experience, varied diets, and plant biochemical diversity. Small Ruminant Research 49:257-274.

Provenza, F. D., J. J. Villalba, J. Haskell, J. W. MacAdam, T. C. Griggs, and R. D. Wiedmeler. 2007. The value to herbivores of plant physical and chemical diversity in time and space. Crop Science 47:382-398.

ReED, J. D. 1995. Nutritional toxicology of tannins and related polyphenols in forage legumes. Journal of Animal Science 73:1516-1528.

Robles, M., M. Arguellin, J. West, and E. Rodriguez. 1995. Recent studies on zoopharmacognosy, pharmacology and neurotoxicology of sesquiterpene lactones. Planta Medica 61:199-203.

Rogers, Q. R., And A. R. Egan. 1975. Amino acid imbalance in the liquid-fed lamb. Australian Journal of Biological Science 28:169-181.

RoSE, S. 1998. Lifelines: biology beyond determinism. New York, NY, USA: Oxford University Press. 335 p.

Rosenthal, G. A., and M. R. Berenbaum. 1992. Herbivores: their interactions with secondary plant metabolites. 2nd ed. New York, NY, USA: Academic Press. $493 \mathrm{p}$.

Rosenthal, G. A., and D. H. Janzen. 1979. Herbivores: their interaction with secondary plant metabolites. New York, NY, USA: Academic Press. 718 p.
Shaw, R. A., J. J. Villalba, and F. D. Provenza. 2006. Resource availability and quality influence patterns of diet mixing with foods containing toxins by sheep. Journal of Chemical Ecology 32:1267-1278.

SkINNER, B. F. 1981. Selection by consequences. Science 213:501-504.

SkINNER, B. F. 1984. The evolution of behavior. Journal of the Experimental Analysis of Behavior 41:217-221.

Sмітн, A. D. 1959. Adequacy of some important browse species in overwintering mule deer. Journal of Range Management 12:9-13.

TILMAN, D. 1982. Resource competition and community structure. Princeton, NJ, USA: Princeton University Press. 296 p.

Villalba, J. J., and F. D. Provenza. 1996. Preference for flavored wheat straw by lambs conditioned with intraruminal administrations of sodium propionate. Journal of Animal Science 74:2362-2368.

Villalba, J. J., and F. D. Provenza. 1997a. Preference for wheat straw by lambs conditioned with intraruminal infusions of starch. British Journal of Nutrition 77:287-297.

Villalba, J. J., and F. D. Provenza. 1997b. Preference for flavoured foods by lambs conditioned with intraruminal administration of nitrogen. British Journal of Nutrition 78:545-561.

Villalba, J. J., and F. D. Provenza. 1997c. Preference for flavored wheat straw by lambs conditioned with intraruminal infusions of acetate and propionate. Journal of Animal Science 75:2905-2914.

Villalba, J. J., and F. D. Provenza. 1999. Nutrient-specific preferences by lambs conditioned with intraruminal infusions of starch, casein, and water. Journal of Animal Science 77:378-387.

Villalba, J. J., and F. D. Provenza. 2000. Postingestive feedback from starch influences the ingestive behaviour of sheep consuming wheat straw. Applied Animal Behaviour Science 66:49-63.

Villalba, J. J., and F. D. Provenza. 2001. Preference for polyethylene glycol by sheep fed a quebracho tannin diet. Journal of Animal Science 79:2066-2074.

Villalba, J. J., and F. D. Provenza. 2002. Polyethylene glycol influences selection of foraging location by sheep consuming quebracho tannin. Journal of Animal Science 80:1846-1851.

Villalba, J. J., And F. D. Provenza. 2007. Self-medication and homeostatic behavior in herbivores: learning about the benefits of nature's pharmacy. Animal 1:1360-1370.

Villalba, J. J., F. D. Provenza, and J. O. Hall. 2008. Learned appetites for calcium, phosphorus, and sodium in sheep. Journal of Animal Science 86:738-747.

Villalba, J. J., F. D. Provenza, J. 0. Hall, and C. Peterson. 2006a. Phosphorous appetite in sheep: Dissociating taste from postingestive effects. Journal of Animal Science 84:2213-2223.

Villalba, J. J., F. D. Provenza, and G. Han. 2004. Experience influences diet mixing by herbivores: Implications for plant biochemical diversity. Oikos 107:100-109.

Villalba, J. J., F. D. Provenza, and R. Shaw. 2006b. Initial conditions and temporal delays influence preference for foods high in tannins and for foraging locations with and without foods high in tannins by sheep. Applied Animal Behaviour Science 97:190-205.

Villalba, J. J., F. D. Provenza, and R. Shaw. 2006c. Sheep self-medicate when challenged with illness-inducing foods. Animal Behaviour 71:1131-1139.

von Schönfeld, J., B. Weisbord, and M. K. Müller. 1997. Silibinin, a plant extract with antioxidant and membrane stabilizing properties, protects exocrine pancreas from cyclosporin A toxicity. Cellular and Molecular Life Sciences 53:917-920.

Wang, J., and F. D. Provenza. 1997. Food deprivation affects preference of sheep for foods varying in nutrients and a toxin. Journal of Chemical Ecology 22:2011-2021.

Wiedmeier, R. D., F. D. Provenza, and E. A. Burritt. 2002. Exposure to ammoniated wheat straw as suckling calves improves performance of mature beef cows wintered on ammoniated wheat straw. Journal of Animal Science 80:2340-2348. 